\title{
Physical, chemical and biological characterization as support for water governance in a hydrogeological system of Colombia
} \author{
Pedro Villegas ${ }^{2}$, Vanessa Paredes ${ }^{2}$ and Carlos Molano ${ }^{3}$ \\ ${ }^{1}$ Universidad de Antioquia, Medellín, Colombia; (juliana.ossav@udea.edu.co) \\ ${ }^{2}$ Corporación para el Desarrollo Sostenible de Urabá-CORPOURABA, Apartadó, Colombia \\ 3 Universidad de los Andes, Bogotá, Colombia
}

Juliana Valencia Ossa ${ }^{1}$, Teresita Betancur ${ }^{1}$, Jhon Duque ${ }^{1}$, Angel Cardona ${ }^{1}$, Laura Pineda ${ }^{1}$,

doi: $10.4154 / g c .2018 .10$

Article history:

Manuscript received January 16, 2018

Revised manuscript accepted June 06, 2018

Available online June 21, 2018
Keywords: layered aquifer, groundwater management, conceptual hydrogeological models, sustainability

\begin{abstract}
Understanding the physical, chemical and biological system is an indispensable precondition to addressing groundwater management. This understanding is based on Conceptual Hydrogeological Models, which contain different interpretations and their validity is checked through the application of specific research techniques (numerical modelling, hydrochemistry, isotope hydrology, process evaluation and biological functions). This paper describes the experience carried out by an academic team that, together with entities responsible for the protection of water resources, established strategic alliances to improve the knowledge of the hydrogeological system, providing new elements for governance. This study was carried out in the Urabá antioqueño zone, located north-west of Colombia. A complex aquifer system is located in the region, characterized by a series of permeable, semi-permeable and impermeable layers. In such a layered aquifer the determination of the physical, chemical and biological characteristics of the layers and their management are a challenge for researchers because groundwater represents a strategic resource for supplying the population and developing economic activities. Starting from the conceptual hydrogeological model, multiscale numerical modelling exercises have been carried out, enabling the characterization of local, intermediate and regional flow systems. In addition, by determining the natural background level, the concentration ranges of chemical compounds from natural sources were obtained, in order to detect future changes in water quality. It was also possible to examine the stygofauna, which allowed the recognition of different types of organisms (stygobits, stygophiles and stygoxens) associated with underground ecosystems. These scientific elements serve as a support for the management instruments such as the groundwater management plan that is important for water governance, ensuring its future sustainability.
\end{abstract}

\section{INTRODUCTION}

Within the water resources, groundwater constitutes a strategic element that fulfills several functions: it contributes to the base flow of surface water streams, maintenance of groundwater dependant ecosystems and is an important source to satisfy human, industrial and agricultural needs. For some time, fresh surface water has been a scarce resource, largely due to increasing population in cities and rising living standards, agricultural and industrial needs increasingly demand water, especially groundwater, since the surface water is susceptible to contamination and scarce in prolonged droughts. It is estimated that approximately half of the world population depends on groundwater for human consumption (WWAP, 2016), which leads to a greater interest in understanding the resource in order to facilitate its adequate management.

Knowledge of the underground water resource is based on the collection of information, with the purpose of schematizing a conceptual hydrogeological model for a study area that allows the geometry and the physical characteristics of the territory to be understood. This includes the identification and delimitation of surface and in-depth hydrogeological units, determination of sources, areas and calculation of recharge, definition of underground flow trends, knowledge of hydraulic properties, quality assessment and knowledge of intrinsic vulnerability. However, all this knowledge and research progress should always seek to improve the management and generation of policies on the sustainability of this resource, in order to move towards better water governance (MINISTERIO DE AMBIENTE Y DESARROLLO SOSTENIBLE, 2014).

This paper presents the hydrogeological advances, taking into account the physical, chemical and biological characteristics of the Hydrogeological System of the Gulf of Urabá in Colombia, which were carried out in the framework of 4 master's studies. These studies aimed to determine and promote responsible collective actions that would ensure the short, medium and long term socially sustainable use of the water resources for the benefit of the community and dependent ecosystems.

The objective of this work is to promote the integration of different fields of research in hydrogeology, which support and complement the hydrogeological conceptual model of an aquifer system, taking into account the most relevant aspects, in terms of hydrodynamic behaviour, hydrogeochemical conditions and the natural chemical background and biological aspects through the identification of stygofauna.

The importance of this work in this area of Colombia is that the groundwater allows the production of bananas (irrigation and washing of the fruit, which represent about $75 \%$ of the total demand for groundwater) in an area about $320 \mathrm{Km}^{2}$ that is the main 


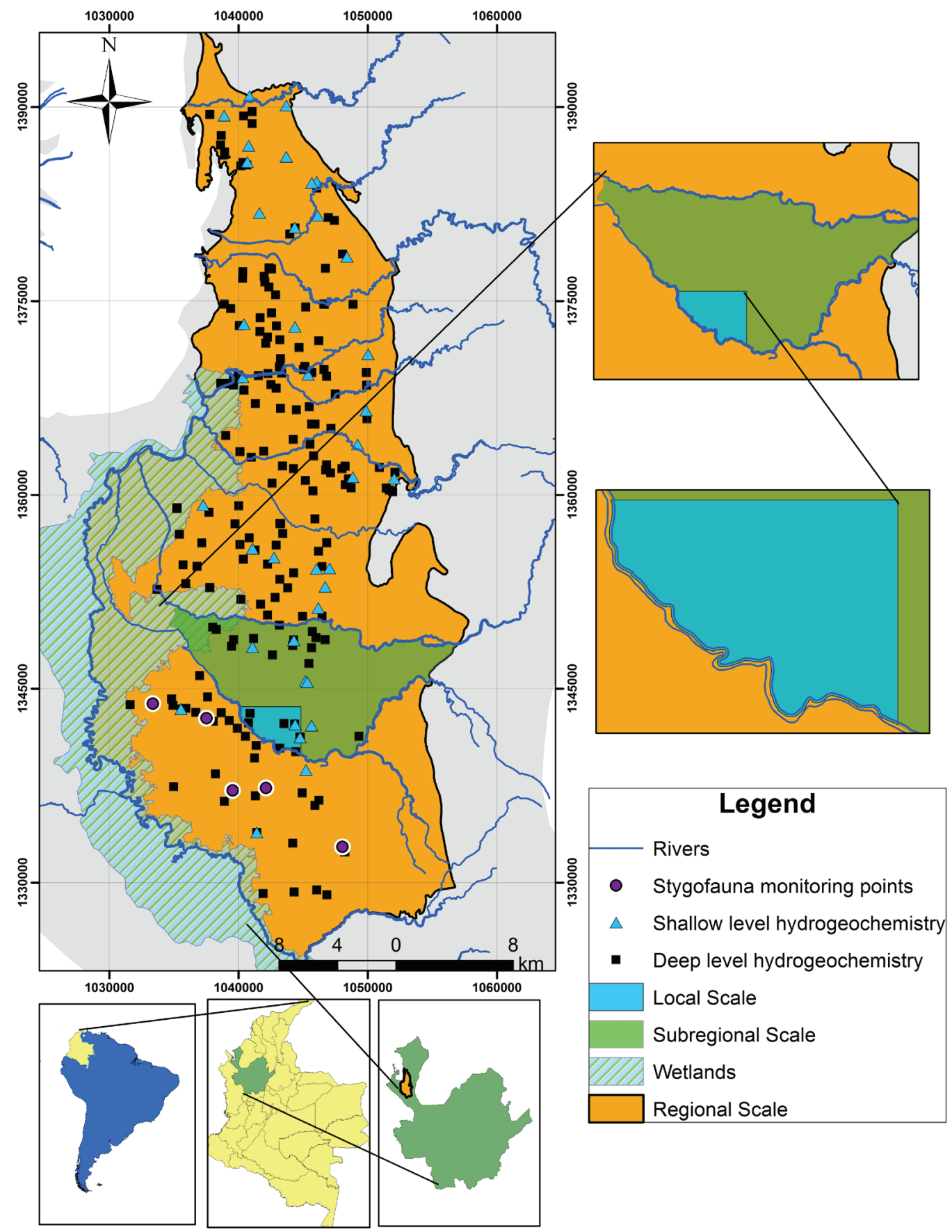

Figure 1. Zone of Study with Description of the Modelling Scales, Sampling Points with Stygofauna and Points of Hydrogeochemical Assessment.

source of employment and income of the region. Groundwater is the main source of domestic water supply for 18 rural communities and two of the four urban headwaters (which represents about $15 \%$ of the total demand for groundwater), making it a strategic resource that must be protected to guarantee the future supply of water for both human supply and for the development of economic activities in the region.

\section{DESCRIPTION OF THE STUDY AREA}

This research was carried out in the Urabá subregion of Antioquia, located in the most northerly corner of South America that coincides with Colombia, in the department of Antioquia. It is located between coordinates $8^{\circ} 10^{\prime} 35$ "N, $7^{\circ} 31^{\prime} 27^{\prime}$ 'S, -76 $46^{\circ} 26^{\prime}$ " $\mathrm{W}$, and $-76^{\circ} 33^{\prime} 13^{\prime \prime} \mathrm{E}$, with an approximate area of $1.206 \mathrm{~km}^{2}$ (Fig. 1). The average air temperature in the region is $28^{\circ} \mathrm{C}$ and the rela- tive humidity is of the order of $85.9 \%$, it also presents an average annual precipitation between $2.100 \mathrm{~mm} /$ year and $3.800 \mathrm{~mm} /$ year and is characterized by a rainy season from April to December and a dry period between January and March.

The hydrogeological system corresponds to an aquifer with multilayer characteristics (Figure $2 \&$ Table 1). This type of system consists of an alternating series of permeable, semi-permeable and impermeable layers. This knowledge was obtained from a detailed hydro stratigraphic correlation exercise using 258 drilling logs, 202 vertical electrical surveys and 107 well electrical records. The system was hydraulically characterized by 158 pumping tests and with information from a piezometric monitoring network with quarterly sampling regime since 1998 CORPOURABA \& UNIVERSIDAD DE ANTIOQUIA (2014) \& DUQUE et al. (2016). 


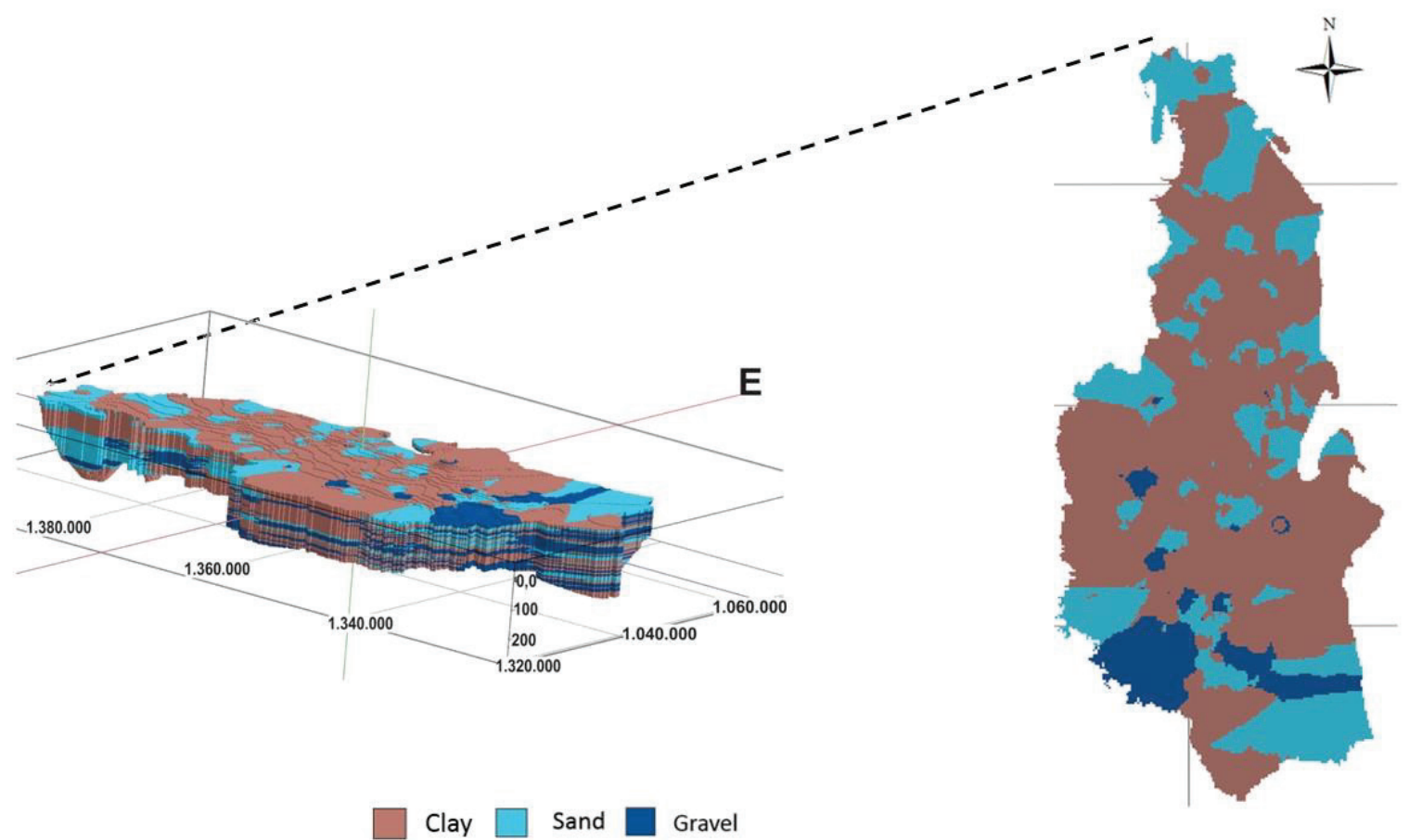

Figure 2. The Multi Layered Aquifer Hydrogeological System of the Gulf of Urabá.

Table 1. Multi Layered Aquifer Properties.

\begin{tabular}{lccc}
\hline Property & Min & Max & Mean \\
\hline Hydraulic conductivity K (m/day) & 0.2 & 28.3 & 6.10 \\
Transmissivity $\left(\mathrm{m}^{2} /\right.$ day) & 1.0 & 1840.0 & 145.7 \\
Thickness $(\mathrm{m})$ & 3 & 300 & 147.9 \\
Depth to groundwater table $(\mathrm{m})$ & 0.3 & 42.0 & 5.1 \\
Specific discharge $(\mathrm{L} / \mathrm{s} / \mathrm{m})$ & 0.05 & 13.6 & 1.5 \\
\hline
\end{tabular}

According to the results of the water balance obtained by CORPOURABA \& UNIVERSIDAD DE ANTIOQUIA (2014), the average recharge in the study area is $270.9 \mathrm{~mm} /$ year.

\section{MATERIALS AND METHODS}

This research started from the setup of the conceptual model and some physical aspects of the hydrogeological system. For the calculation of the groundwater supply, favourable areas for recharge were taken into account in which the upper levels of the aquifer system are composed of sands and gravels. In addition, to four stations, the water balance was calculated, considering dry year scenarios. These stations record the evaporation data, or are close to the stations with data record of the evaporimeter tank and flow. In addition, the location of the space was taken into account, seeking a better representation of the entire study area, establishing areas of influence through the Thiessen polygons. On the other hand, the demand for groundwater was calculated from the information collected from the databases existing at the environmental authority of the zone (CORPOURABA). It took into account the groundwater points and the current concession volume for abstraction points that are legalized along with their pumping regime. The characterization of the terrestrial cover corresponded to level 2, according to the nomenclature exposed by the CORINE Land Cover CLC methodology. Results come from the re- port on the semi-detached survey of land cover for the Department of Antioquia, carried out by IGAC \& GOBERNACIÓN DE ANTIOQUIA (2007), at a scale of 1:25.000. The piezometric analysis was performed taking into account the modelling of piezometric surfaces for the average dry season and rainfall, in order to visualize trends in the underground flow dynamics.

In addition, in order to more accurately represent this dynamic in a better way, a multi-scale (regional, intermediate and local) numerical modelling exercise (JOYCE et al., 2014) was carried out in permanent and transient state to identify the flow systems present in the aquifer using the modelling software Groundwater Vistas ${ }^{\circledR}$ (Environmental Simulations Incorporated 2015). This is a graphical interface of the MODFLOW model, and simulated the ground-water flow using a block-centered finite-difference approach HARBAUGH \& MCDONALD (1996), where the model at the regional level provides the boundary and initial conditions of the intermediate model and these in turn the local model. For the three models, the following conditions have been established:

i) For the regional model that completely covers the study area, $100 \mathrm{~m} \times 100 \mathrm{~m}$ cells were defined and three layers were constructed for an area of $1,206 \mathrm{~km}^{2}$.

ii) For the intermediate model, information was collected from 73 drilling registers, 42 vertical electrical drills and 1 well electrical $\log , 20 \mathrm{~m} \times 20 \mathrm{~m}$ cells were defined in an area of 123 $\mathrm{km}^{2}$, and five layers were constructed to represent the heterogeneity of the geometry.

iii) For the local model with an area of $25 \mathrm{~km}^{2}, 10 \mathrm{~m} \times 10 \mathrm{~m}$ cells were defined and seven layers were constructed, with information from 22 drilling logs, 8 vertical electrical probes and 1 well $\log$.

In all cases the following boundaries were considered and incorporated in Groundwater Vistas ${ }^{\circledR}$ : River, General Head Boundary, Well and Drain to represent the wetlands. In the regional model the Constant Head border was additionally used to 
represent the Gulf. The hydraulic conductivity $(\mathrm{K})$ was calibrated according to data of pumping tests performed in the study area. Taking into account the hydroclimatological characteristics of Urabá for the transient calibration, three periods of stress were defined: the first between December 2010 and March 2011, the second between April and September 2011 and the third between October and November of 2011. The initial conditions for the modelling in transient state were taken from the model in calibrated permanent state. The initial recharge values applied to the model were different depending on the textural characteristics of the first layer three recharge zones were defined (clays, sands and gravels). The calibration was performed using the PEST automatic calibration module incorporated into the Groundwater Vistas software. In addition, sensitivity analyses were conducted to evaluate the response of the piezometric levels and the mass balance from the controlled modification of hydraulic properties and boundary conditions (General Head Boundary, Rivers and Drain).

The knowledge of the chemical characteristics of the system was acquired through the determination of natural chemical background levels, which according to EDMUNDS et al. (2003) and SHAND et al. (2007) correspond to the concentration of a particular element, species or chemical composition of groundwater present in solution that is derived from natural sources: geological, biological or atmospheric. For application of this study, the shallow and deep water bodies were separated: the depth of shallow levels was less than $30 \mathrm{~m}$ and the deep levels were greater than $30 \mathrm{~m}$, samples with a balance error higher than $15 \%$ were discarded, with 69 samples for shallow and 262 samples for the deep level. In addition the analytical quality of the chemical analysis data was verified with the ionic relations proposed by HOUNSLOW (1995). The sampling protocol followed is described in greater detail in OSSA \& BETANCUR (2018).

Furthermore, in order to determine higher concentrations of the natural chemical background, the 90 and 95 percentiles were used based on the amount of information on each parameter, $(90$ for less than 60 samples and 95 for more than 60 samples). Samples with a concentration of $\mathrm{NO}_{3}{ }^{-}$above $10 \mathrm{mg} / \mathrm{L}$ were previously discarded. For the biological characterization the organisms belonging to the stygofauna were considered. For this, a biological monitoring network was formed with five wells that present an electrical conductivity gradient (EC) between 82.5 and $1,360 \mu \mathrm{s} /$ $\mathrm{cm}$ and depths ranging from 3.2 to $5.26 \mathrm{~m}$. From the selected wells, samples were taken in both the dry and wet periods. The samples were taken with two meshes of 180 and $39 \mu \mathrm{m}$ respectively to obtain organisms. For sampling, the meshes are lowered to the bottom of the well where the sediments are shaken for a period of 20 seconds, after this step the meshes are collected and washed with distilled water, the contents are transferred to labelled containers for laboratory identification (MALARD et al., 2002); HAHN \& MATZKE (2005); BOULTON et al., 2008); \& TIONE et al., 2014). All water samples with possible biological content were preserved with analytical grade alcohol and transported in iceboxes for laboratory analysis. The biological samples were analyzed by two qualitative procedures, which consist of counting the morphotypes using an optical microscope, in order to obtain the number of individuals per millilitre in the samples, and another quantitative analysis carried out by means of an inverted microscope which shows the morphotypes of the samples in order to identify them by taxonomic registration. These two procedures allow the determination of the type and quantity of microorganisms in the samples.

\section{RESULTS}

For the groundwater supply, a weighted average recharge of $270.9 \mathrm{~mm} /$ year was calculated. This value, distributed between actual recharge surfaces for shallow levels $\left(323.0 \mathrm{Km}^{2}\right)$ and those in which infiltration is possible that later acts as recharge for the deep levels $\left(137.4 \mathrm{Km}^{2}\right)$ allows the estimation of an approximate value of the volume of annual water that would enter the system: $87.5 \mathrm{Mm}^{3}$ to the unconfined aquifer and $37.2 \mathrm{Mm}^{3}$ to the confined aquifer. The current demand for groundwater is $24 \mathrm{Mm}^{3} /$ year. The utilization rate for each sector is as follows: households $15.9 \%$, industry $7.9 \%$, agriculture $75.8 \%$ and livestock production $0.4 \%$. In the study area, the most extensive land use is the permanent crops with $37.01 \%$ of the total area, which is linked to the agricultural activity of banana cultivation and a further $31.57 \%$ for grazing.

The modelling of the average piezometric surface in the rainy season shows that the general tendency of the groundwater flow in the aquifer travels from the Serranía de Abibe to the channel of the Lion river in the centre and south, and to the Gulf of Urabá, following a southeast-northwest direction to the north of the study area (Figure 3). However, the average piezometric surface for the dry season evidences alterations in the flow direction, presenting in some sections low piezometric heads, because the irrigation wells, used for agricultural activity of the banana, are only pumped during this period.

Regarding the modelling result both for the steady state and transient, this is considered satisfactory according to the literature as Pearson correlation coefficients were between $77 \%$ and $95 \%$ in the three modelling scales. During the calibration exercise, it was possible to detect that the model is more sensitive to recharge (The recharge values calibrated in the three periods defined for the year 2011 are presented in Table 2) and water level in the rivers, since these generate significant ascents or descents in the aquifer's piezometric levels. Finally, it was possible to identify following the direction of the east-west flow shown in the piezometric surface modelled (Figure 3 ) that on a regional scale the equipotentials pseudo-parallel flow to the surface, even in the border neighbourhoods, River and Drain. In the intermediate model these equipotentials show a tendency to interact with wetlands and rivers, then with the detail of the local model, the better defined equipotentials show the relationship between groundwater and surface waters (Figure 4). It is clear that this is an effect of the refinement that can be achieved when there is a better resolution with more representative information, which at the same time allows the discretization of the data and more representative geometry of the hydrogeological system.

The hydrogeochemistry, in terms of anion composition, shows that the groundwater of the evaluated system has a bicarbonate nature, with significant variations in the content of cations. The hydrochemical evolution of $\mathrm{Ca}^{2+}-\mathrm{HCO}_{3}{ }^{-}$and $\mathrm{Ca}^{2+}-\mathrm{Mg}^{2+}$ $\mathrm{HCO}_{3}{ }^{-}$facies, include silicate and carbonate weathering processes, as well as ion exchange processes of $\mathrm{Mg}$ and $\mathrm{Ca}$ to $\mathrm{Na}$ (OSSA \& BETANCUR, 2016). The hydrogeochemical evolution

Table 2. Calibrated Recharge.

\begin{tabular}{lccc}
\hline \multirow{2}{*}{ Period } & \multicolumn{3}{c}{ Recharge (mm/day) } \\
\cline { 2 - 4 } & zone 1 (clays) & zone 2 (sands) & zone 3 (Gravels) \\
\hline December (2010)-March(2011) & 0.3 & 0.7 & 1 \\
\hline April-September (2011) & 0.3 & 0.6 & 0.9 \\
\hline October-November (2011) & 0.2 & 0.5 & 0.7 \\
\hline
\end{tabular}




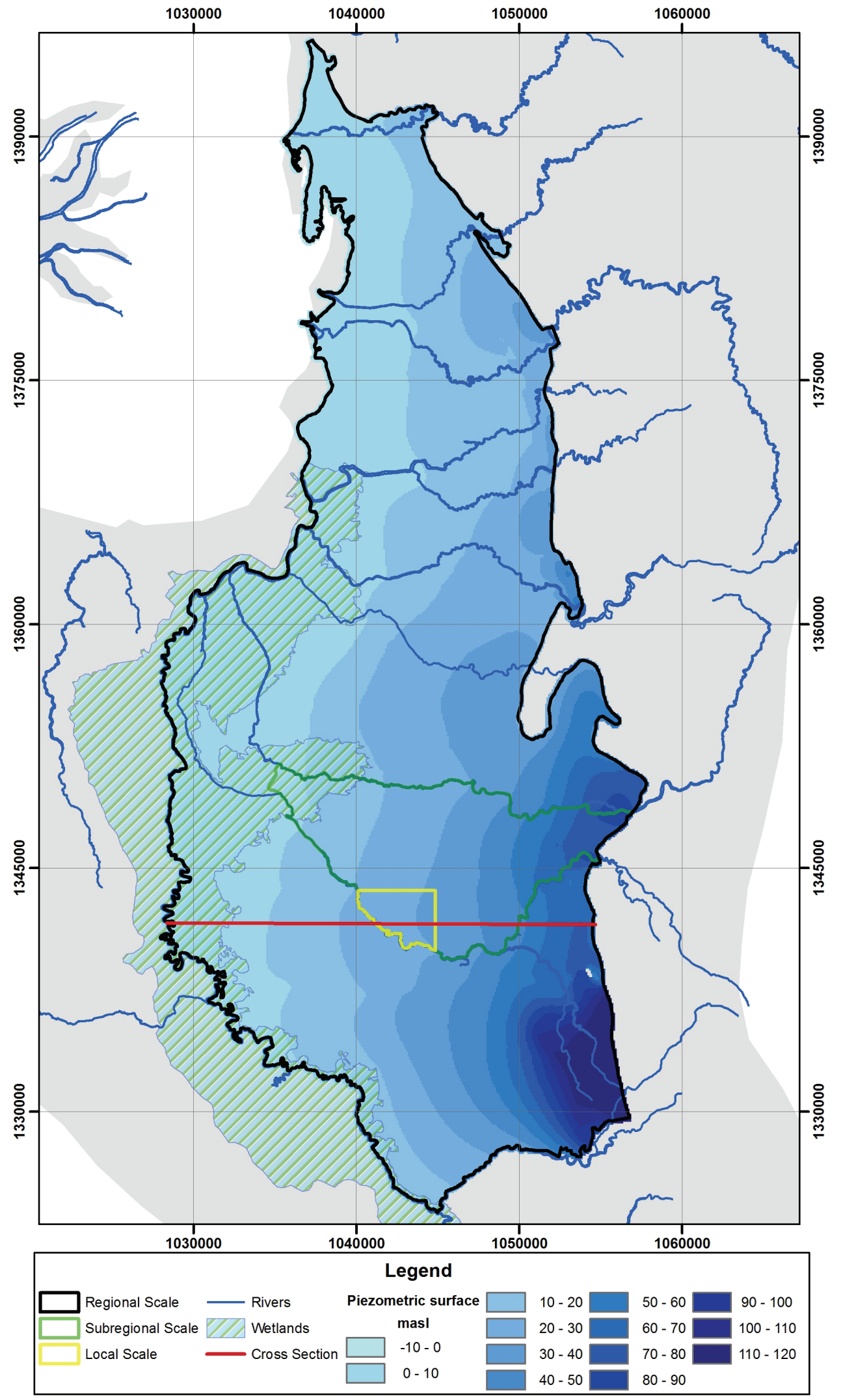

Figure 3. Piezometric surface and cross section.

of the groundwater shows regional differences related to various features, among which the following stand out: variability in the stratigraphic characteristics of the system, differences in the degrees of connection between permeable layers, changes in the conditions of hydraulic conductivity, variation in the depth of the captured layers of the aquifer, and differences in the distance to the zones of recharge (OSSA \& BETANCUR, 2018).

The greater confinement of the aquifer system is found towards the center and north, with a recharge zone to the east in the foothills of the Abibe Mountains, showing greater mineralization 


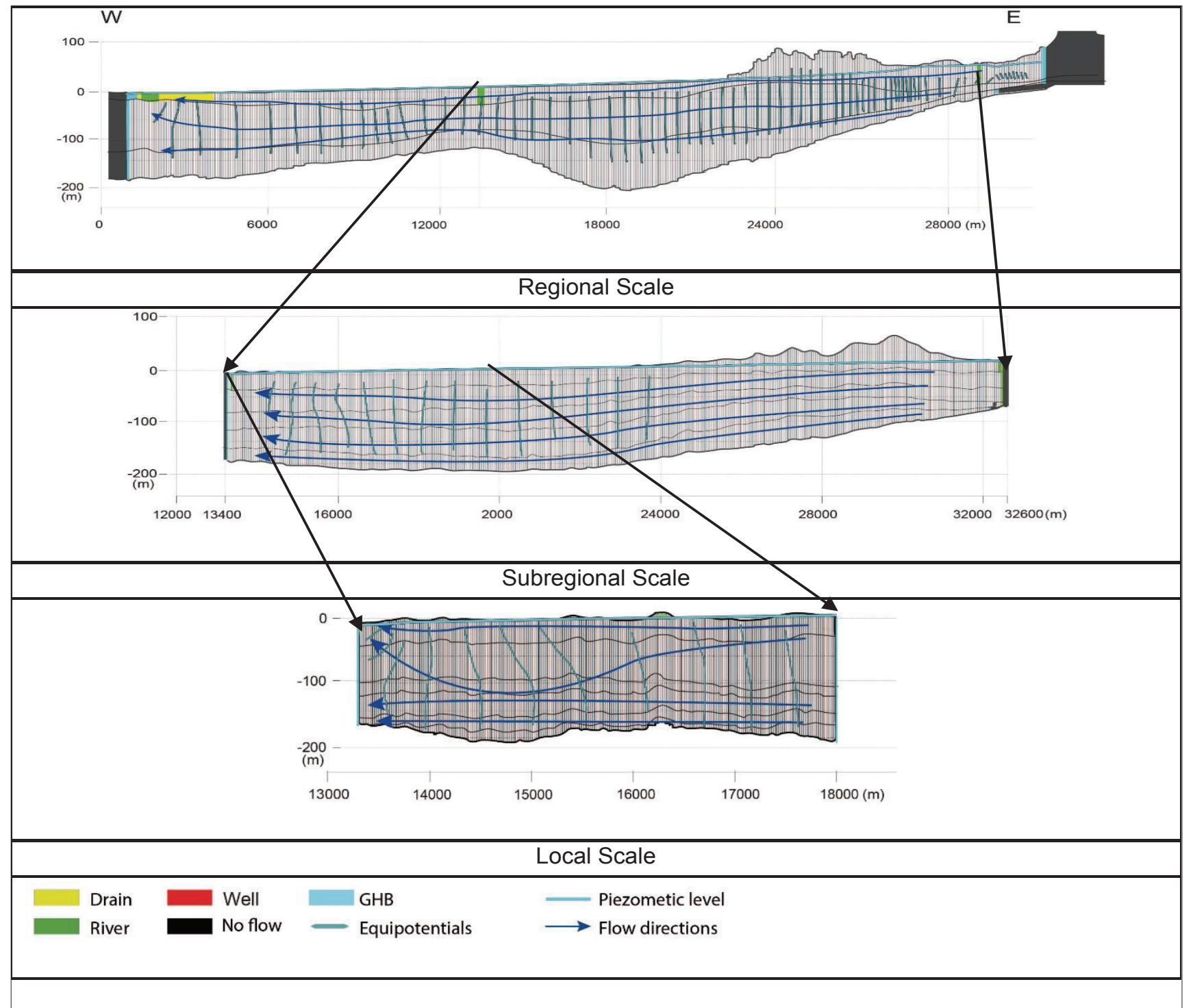

Figure 4. Flow Direction vs Scale of Modelling.

to this area. In the southern part of the study zone, the biggest connection between the multilayer aquifer system and meteoric conditions occur through the permeable layers, showing less evolved and mineralized waters towards this zone (OSSA \& BETANCUR, 2018). In the shallow levels, in addition, there may be affectations to the chemistry of the groundwater by anthropogenic contamination from agricultural activities, livestock, poor management of solid waste, and the lack of sewer system.

With regard to the levels and composition of the natural chemical background, Table 3 summarizes the values for the lower and upper limits of each chemical parameter, considering the percentiles as mentioned above based on the number of samples belonging to each parameter. In addition, the median is presented, as a central value which is less sensitive to extremes. These concentrations are presented by differentiating the deep and shallow levels, since the chemical characteristics can vary significantly with depth.

An outcome of the biological characterization, (from the observation of samples analyzed in the laboratory using the methodologies described above), stygofauna were detected in four of the five sampling points. The stygofauna belong to groups of organisms including: macroinvertebrate larvae, nematodes, vari- ous metazoans, amoebas, copepods in different stages, ostracods, cladocerans, and different types of algae that may be the result of the interaction between the superficial water and the aquifer (Figure 5). Table 4 shows the distribution of the organisms in each of the sampling periods (wet season: November or dry season: March). It has been observed that the copepod and nematode morphotypes disappeared in the dry season while a new morphotype appears in the dry season known as cladocerans. Regarding the dominance of morphotype by sampling periods, copepods dominate in the wet season, while ostracods dominate in the dry season.

\section{CONCLUSIONS}

According to the conceptual hydrogeological model in the Urabá region the aquifer has multilayer characteristics, with variations in the permeability of the layers, from the low permeability clayey aquitard layers located predominantly in the North, to the more permeable layers toward the central and southern areas. In addition, the permeable layers occur at times at the surface constituting an unconfined system but in some areas these are separated from the surface by thick clayey layers that characterise a confined or semi-confined aquifer. These elements make this sys- 
Table 3. Natural Chemical Background Levels for the Hydrogeological System of the Gulf of Urabá.

\begin{tabular}{|c|c|c|c|c|c|c|c|c|}
\hline \multirow{2}{*}{ Parameter } & \multicolumn{4}{|c|}{ Deep aquifer (greater than $30 \mathrm{~m}$ ) } & \multicolumn{4}{|c|}{ Shallow aquifer (less than $30 \mathrm{~m}$ ) } \\
\hline & Lower value & Upper value & Median & $\begin{array}{c}\text { Number of } \\
\text { samples }\end{array}$ & Lower value & Upper value & Median & $\begin{array}{l}\text { Number } \\
\text { of samples }\end{array}$ \\
\hline $\mathrm{pH}$ & 5.45 & 7.60 & 6.88 & 79 & 5.95 & 7.13 & 6.72 & 52 \\
\hline $\mathrm{T}\left({ }^{\circ} \mathrm{C}\right)$ & 26.20 & 28.52 & 26.90 & 69 & 27.10 & 29.55 & 28.55 & 46 \\
\hline $\mathrm{EC}(\mu \mathrm{S} / \mathrm{cm})$ & 73.00 & 2455.15 & 642.50 & 88 & 36.55 & 960.00 & 411.10 & 59 \\
\hline TDS (mg/L) & 56.00 & 1499.80 & 423.00 & 68 & 20.00 & 624.80 & 228.00 & 59 \\
\hline $\mathrm{Na}^{+}(\mathrm{mg} / \mathrm{L})$ & 0.35 & 346.64 & 74.00 & 89 & 1.00 & 82.02 & 26.20 & 59 \\
\hline $\mathrm{K}^{+}(\mathrm{mg} / \mathrm{L})$ & 0.10 & 12.65 & 1.92 & 83 & 0.10 & 7.53 & 2.03 & 59 \\
\hline $\mathrm{Mg}^{2+}(\mathrm{mg} / \mathrm{L})$ & 0.71 & 116.21 & 18.50 & 89 & 1.97 & 33,66 & 11.41 & 59 \\
\hline $\mathrm{Ca}^{2+}(\mathrm{mg} / \mathrm{L})$ & 3.67 & 140.60 & 33.00 & 89 & 7.70 & 80.94 & 34.60 & 59 \\
\hline $\mathrm{Mn}^{2+}(\mathrm{mg} / \mathrm{L})$ & 0.08 & 1.60 & 0.83 & 61 & 0.04 & 3.00 & 0.98 & 59 \\
\hline $\mathrm{NH}_{4}{ }^{+}(\mathrm{mg} / \mathrm{L})$ & 0.07 & 2.94 & 1.02 & 24 & 0.03 & 0.81 & 0.28 & 22 \\
\hline $\mathrm{Fe}^{3+}(\mathrm{mg} / \mathrm{L})$ & 0.02 & 8.48 & 1.72 & 85 & 0.05 & 7.02 & 2.09 & 58 \\
\hline $\mathrm{Cl}^{-}(\mathrm{mg} / \mathrm{L})$ & 0.54 & 489.84 & 6.26 & 89 & 0.74 & 71.48 & 16.14 & 59 \\
\hline $\mathrm{SO}_{4}{ }^{2-}(\mathrm{mg} / \mathrm{L})$ & 0.42 & 36.70 & 4.57 & 84 & 1.50 & 56.38 & 18.00 & 58 \\
\hline $\mathrm{HCO}_{3}^{-}(\mathrm{mg} / \mathrm{L})$ & 26.84 & 975.80 & 397.72 & 89 & 31.00 & 478.35 & 150.74 & 59 \\
\hline $\mathrm{CO}_{3}^{-}(\mathrm{mg} / \mathrm{L})$ & 0.00 & 0.00 & 0.00 & 80 & 0.00 & 0.00 & 0.00 & 18 \\
\hline $\mathrm{NO}_{3}^{-}(\mathrm{mg} / \mathrm{L})$ & 0.00 & 7.75 & 0.22 & 89 & 0.02 & 6.28 & 1.46 & 59 \\
\hline $\mathrm{PO}_{4}^{3-}(\mathrm{mg} / \mathrm{L})$ & 0.01 & 5.29 & 1.99 & 33 & 0.00 & 1.03 & 0.15 & 28 \\
\hline $\mathrm{Si}(\mathrm{mg} / \mathrm{L})$ & 6.72 & 44.88 & 34.80 & 22 & 4.85 & 13.95 & 10.44 & 6 \\
\hline
\end{tabular}

tem complex, both in the understanding of its physical and chemical characteristics, as well as in relation to its management.

Comparing demand versus supply, and taking into account the groundwater scarcity indicator in Colombia, regulated by Resolution 872 (2006) and considering that this multilayer aquifer can obtain contributions from the shallow levels and by distant flows, it was concluded that the water scarcity index of the Hydrogeological System is between medium high and high.

The Modelling is satisfactory; the Pearson correlation coefficients are between $77 \%$ and $95 \%$ for the three modelling scales, representing magnitudes that are in accordance with those recommended in the literature. With the multi-scale numerical modelling, it was possible to nest a local model within an intermediate model and these within a regional model, allowing - to the extent that resolution and detail were gained - to transcend from the characterization of regional flows to the identification of intermediate and local flows, in which the interaction between groundwater and surface water was evidenced, involving not only shallow levels of the multilayer aquifer system, but evidencing the occurrence of upward flows. The results of numerical modelling are consistent with the conceptual flow model and reproduce validated trends using hydrogeochemical and isotopic techniques (OSSA \& BETANCUR, 2018).

Table 4. Density of Stygofauna Organisms occurring in Samples.

\begin{tabular}{|lcc|}
\hline Parameter & November 2015 & March 2016 \\
\hline Ostracod density (organisms/ml) & 7.464 & 8.362 \\
Copepod density (organisms/ml) & 9.875 & 0 \\
Nematodes density (organisms/ml) & 8.281 & 0 \\
Cladocerans density (organisms/ml) & 0 & 472 \\
Total density organisms $/ \mathrm{ml})$ & 21.273 & 8.834 \\
average temperatura $\left(\mathrm{C}^{\circ}\right)$ & 28.3 & 28.7 \\
Average dissolved oxygen $(\mathrm{mg} / \mathrm{ml})$ & 4.0 & 4.4 \\
Average electric conductivity $(\mu \mathrm{s} / \mathrm{cm})$ & 358.4 & 524.2 \\
\hline
\end{tabular}

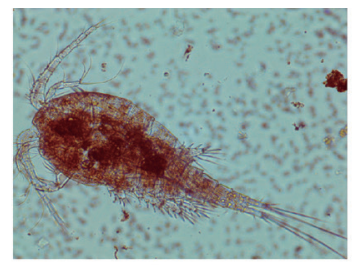

Copepod Stygophiles

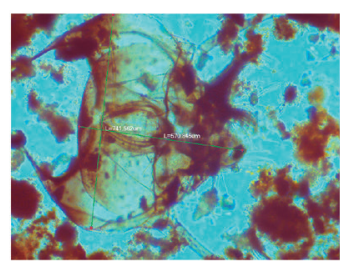

Cladocerans (Bosmina sp) Stygophiles

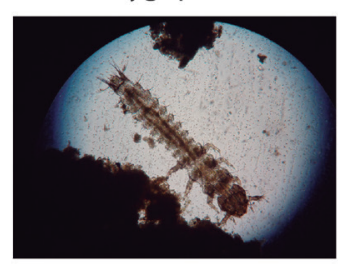

Macroinvertebrates (coleopteran sp) Stygoxenes

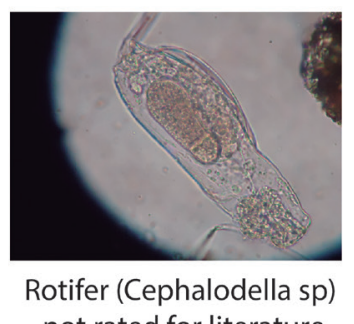

not rated for literature

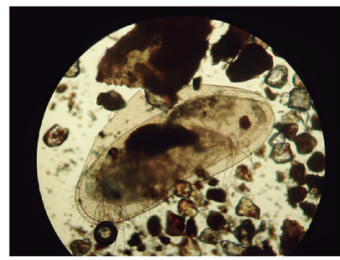

Ostracod (Eucypris sp) Stygophiles

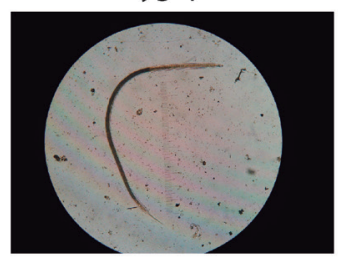

Nematodoes (Rhabditis sp) Stygophiles

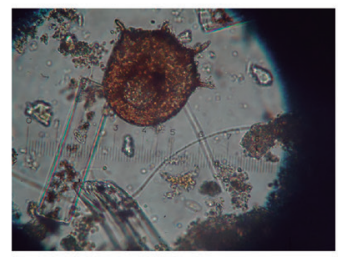

Amoeba (Centropyxis sp) not rated for literature

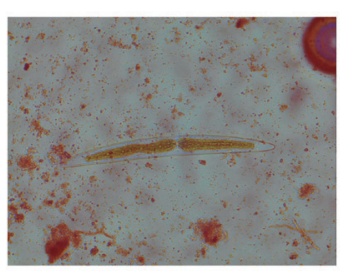

Algae (Closterium sp) not rated for literature
Figure 5. Morphotypes of Detected Stygofauna in the Hydrogeological System of the Gulf of Urabá. 
Natural background values are a starting point for the environmental authority to issue regulatory standards to identify subsequent changes in quality, recognizing abnormal concentrations beyond these concentration limits of upper values. The upper values in parameters such as electric conductivity, TDS, $\mathrm{Fe}, \mathrm{SO}_{4}$ are greater than the values required in Colombian regulations, however, these parameters may be above those resulting from natural conditions such as permeability, stratigraphic conditions, system of flows. It should be borne in mind that these concentration ranges are applicable only to this aquifer, since the other systems may have different geological, chemical, atmospheric conditions, among others, that can considerably alter these ranges. However, the methodology used can be applied to all other systems.

It was possible to verify the presence of stygofauna in the shallow levels of the Urabá multilayer aquifer. Previously and at present, it is not possible to establish a clear correlation between the density of morphotypes with some physicochemical characteristics of the groundwater; therefore, future sampling is proposed in order to obtain more data that allow the creation of a data matrix with enough elements to create a quality indicator.

This work opens a new line of interdisciplinary research among hydrogeologists, ecologists and biologists, which is useful for gaining a better understanding of environmental systems and for the integrated adequate management of groundwater as an ecosystem.

A significant contribution is that the present study is the first work carried out in Colombia with the purpose of identifying the presence of stygofauna in an aquifer system and to seek relationships between the detected species and the quality of the water.

Finally, all the improvement of hydrogeological knowledge in this Colombian Aquifer System generates the need to implement new policies, agreements and instruments that are consistent with these new findings. This, complemented by the cultural and participative knowledge of the social actors who are part of the territory and who have some role in the groundwater, will help to improve the governance of the water resource in the region.

\section{ACKNOWLEDGEMENT}

This work was possible thanks to the financial aid from CORPOURABA and COLCIENCIAS "Patrimonio Autónomo Fondo Nacional de Financiamiento para la Ciencia, la Tecnología y la Innovación Francisco José de Caldas".

\section{REFERENCES}

BOULTON, A.J., FENWICK, G.D., HANCOCK, P.J. \& HARVEY, M.S. (2008): Biodiversity, functional roles and ecosystem services of groundwater invertebrates.Invertebrate Systematics, 22/2, 103-116. doi: 10.1071/IS07024

CORPOURABA \& UNIVERSIDAD DE ANTIOQUIA (2014): Actualización del Modelo Hidrogeológico Conceptual del Sistema Acuífero del Urabá antioqueño.-Medellín.

DUQUE, J., BETANCUR, T., GARCIA, D., PALACIO, P., PAREDES, V. \& VILLEGAS, P. (2016): Modelación de la geometría de un sistema acuífero complejo multicapa. Caso de estudio: Urabá antioqueño, Colombia.- Revista Latino-Americana de Hidrogeología, 10/1, 7.

EDMUNDS, W.M., SHAND, P., HART, P. \& WARD, R.S. (2003): The natural (baseline) quality of groundwater: A UK pilot study.-The Science of the Total Environment, $310 / 1-3,25-35$.

ENVIRONMENTAL SIMULATIONS INCORPORATED (2015): Groundwater Vistas Manual, from http://www.groundwatermodels.com/Groundwater_Vistas.php

HAHN, H.J. \& MATZKE, D. (2005): A comparison of stygofauna communities inside and outside groundwater bores.- Limnologica - Ecology and Management of Inland Waters, 35/2, 31-44. doi: 10.1016/j.limno.2004.09.002

HARBAUGH, A. \& MCDONALD, M. (1996): User's Documentation for MODFLOW-96, an update to the U.S. Geological Survey Modular Finite-Difference Ground-Water Flow Model. Open-File Report, US Geological Survey, 96-485.

HOUNSLOW, A. (1995): Water Quality Data: analysis and interpretation, 1st. ed. Oklahoma, USA: CRC Press, 1995, 397 p.

IGAC \& GOBERNACIÓN DE ANTIOQUIA (2007): Levantamiento semidetallado de las coberturas terrestres, Departamento de Antioquia. Bogotá.

JOYCE, S., HARTLEY, L., APPLEGATE, D., HOEK, J. \& JACKSON, P. (2014): Multi-scale groundwater flow modelling during temperate climate conditions for the safety assessment of the proposed high-level nuclear waste repository site at Forsmark, Sweden.- Hydrogeology Journal, 22, 1233-1249. doi.org/10.1007/s10040014-1165-6.

MALARD, F., DOLE-OLIVIER, M.J., MATHIEU, J. \& STOCH, F. (2002): Sampling manual for the assessment of regional groundwater biodiversity. Protocols for the ASsessment and Conservation of Aquatic Life in the Subsurface (PASCALIS) 2001/1, 1-27.

MINISTERIO DE AMBIENTE Y DESARROLLO SOSTENIBLE (2014): Guía para la Formulación de Planes de Manejo Ambiental de Acuíferos, Bogotá.

MINISTERIO DE AMBIENTE, VIVIENDA Y DESARROLLO TERRITORIAL (2006): Resolución 872 de 2006, Metodología para el cálculo del índice de escasez para Aguas Subterráneas. Bogota D.C.

OSSA, J. \& BETANCUR, T. (2018): Hydrogeochemical characterization and identification of a system of regional flow. Case study: the aquifer on the Gulf of Urabá, Colombia.- Revista Facultad de Ingeniería, 89, 9-18. doi: 10.17533/udea.redin. n86a02

SHAND, P., EDMUNDS, W.M., LAWRENCE, A.R., SMEDLEY, P. \& BURKE, S, (2007): The natural (baseline) quality of groundwater in England and Wales, p. 72.

TIONE, M.L. \& BLARASIN, M. (2014): Cuaderno de estudios de aguas subterraneas: El acuifero como ecosistema I. (eds.): comunidades de invertebrados en aguas subterráneas y su relación con variables ambientales. Argentina, 2014/ 1, 1-21.

WWAP (United Nations World Water Assessment Programme) (2016): The United Nations World Water Development Report 2016.- Water and Jobs, Paris, p. 148. 